\title{
Renal Sympathetic Ablation Using an Irrigated-Tip Catheter: An Attractive Option?
}

\author{
Rodolfo Staico ${ }^{1}$, Luciana Armaganijan², Cristiano Dietrich ${ }^{3}$, Alexandre Abizaid ${ }^{4}$, Dalmo Moreira ${ }^{5}$, \\ Renato Lopes ${ }^{6}$, Joaquim Almeida ${ }^{7}$, Marcello Franco ${ }^{8}$
}

\begin{abstract}
Background: Catheter-based renal sympathetic denervation has emerged as an adjunct strategy to control refractory hypertension. No studies have yet compared the tissue effects of different catheters, powers and time periods of radiofrequency application, which was the objective of this study. Methods: Six porcine renal arteries were sectioned in their longitudinal axis and placed in the flow chamber designed to simulate physiological renal flow conditions. The catheters were placed obliquely to the artery with constant contact pressure. Radiofrequency ablations were performed using three different catheters: $4 \mathrm{~mm} / 5$ F solid-tip electrode, $4 \mathrm{~mm} / 7 \mathrm{~F}$ solid-tip electrode, and open irrigated-tip $4 \mathrm{~mm} / 7 \mathrm{~F}$ electrode. Two different powers were used ( $8 \mathrm{~W}$ and $15 \mathrm{~W}$ ) for 30,60 and 120 seconds. Results: A total of 18 ablations were performed. More significant nerve damage was observed with the $4 \mathrm{~mm} / 5 \mathrm{~F}$ catheter and power of $8 \mathrm{~W}$ only when the application duration was extended to 120 seconds. On the other hand, significant nerve damage was observed with the $4 \mathrm{~mm} / 7 \mathrm{~F}$ catheter with all power (8 $\mathrm{W}$ and $15 \mathrm{~W}$ ) and duration (30, 60, and 120 seconds) options tested. Deeper lesions were observed with the use of the irrigated catheter, regardless of power and time periods of radiofrequency application. Conclusions: The irrigated-tip catheters produce deeper lesions than solid-tip catheters and their use might be more beneficial in treating patients with renal sympathetic denervation. The clinical applicability of these results, however, should be confirmed.
\end{abstract}

DESCRIPTORS: Hypertension. Renal artery. Sympathectomy. Catheter ablation.
RESUMO

\section{Ablação da Atividade Simpática Renal com Cateter de Ponta Irrigada: Uma Opção Atraente?}

Introdução: A denervação simpática renal por meio de cateteres surgiu como estratégia adjunta para o controle da hipertensão arterial resistente. Nenhum estudo até o momento comparou os efeitos teciduais de diferentes cateteres, potências e tempos de aplicação da radiofrequência, objetivo do presente estudo. Métodos: Seis artérias renais de porco foram seccionadas em seu eixo longitudinal e colocadas em uma câmara projetada para simular condições fisiológicas de fluxo renal. Os cateteres foram posicionados obliquamente à artéria, mantendo-se pressão de contato constante. Aplicações de radiofrequência foram realizadas utilizando-se três diferentes dispositivos: eletrodo de ponta sólida $4 \mathrm{~mm} / 5 \mathrm{~F}$, eletrodo de ponta sólida $4 \mathrm{~mm} / 7 \mathrm{~F}$, e eletrodo com ponta aberta irrigada $4 \mathrm{~mm} / 7 \mathrm{~F}$. Duas energias foram aplicadas $(8 \mathrm{~W}$ e $15 \mathrm{~W})$, durante 30 segundos, 60 segundos e 120 segundos. Resultados: No total foram realizadas 18 aplicações. Injúria neural renal mais significativa foi observada utilizando-se cateter $4 \mathrm{~mm} / 5 \mathrm{~F}$ e energia de $8 \mathrm{~W}$ apenas quando a duração da aplicação foi estendida a 120 segundos. Por outro lado, significante dano neural foi observado com o cateter $4 \mathrm{~mm} / 7 \mathrm{~F}$ com todas as potências ( $8 \mathrm{~W}$ e $15 \mathrm{~W}$ ) e durações testadas (30 segundos, 60 segundos e 120 segundos). Lesões mais profundas foram notadas quando o cateter irrigado foi utilizado, independentemente da potência e da duração da aplicação. Conclusões: $\mathrm{O}$ cateter com ponta irrigada produz lesões mais profundas que os cateteres de ponta sólida e seu uso pode ser mais vantajoso na denervação simpática renal. A aplicabilidade clínica desses resultados, entretanto, deve ser confirmada.

DESCRITORES: Hipertensão. Artéria renal. Simpatectomia. Ablação por cateter.

\footnotetext{
${ }^{1}$ Doctor. Interventionist cardiologist physician at the Invasive Cardiology Service of Instituto Dante Pazzanese de Cardiologia. São Paulo, SP, Brazil. ${ }^{2}$ Cardiologist physician at the Electrophysiology and Heart Arrythmias Medical Section of Instituto Dante Pazzanese de Cardiologia. Fellow in research at the Masters of Health Science in Clinical Research program of Duke University (Durham, Estados Unidos). São Paulo, SP, Brazil.

${ }^{3}$ Cardiologist physician at Universidade Federal de São Paulo. São Paulo, SP, Brazil.

${ }^{4}$ Full professor. Director of the Invasive Cardiology Service of Instituto Dante Pazzanese de Cardiologia. São Paulo, SP, Brazil.

${ }^{5}$ Doctor. Head of the Electrophysiology and Heart Arrythmias Medical Section of Instituto Dante Pazzanese de Cardiologia. São Paulo, SP, Brazil.
}

\footnotetext{
${ }^{6}$ Doctor. Cardiologist physician at Universidade Federal de São Paulo. Director of the Instituto Brasileiro de Pesquisa Clínica. São Paulo, SP, Brazil.

7 Biologist. Technician in Histology at the Pathology Department of Universidade Federal de São Paulo. São Paulo, SP, Brazil.

${ }^{8}$ Principal professor at the Pathology Department of Universidade Federal de São Paulo. São Paulo, SP, Brazil.
}

Correspondence to: Rodolfo Staico. Av. Dr. Dante Pazzanese, 500 - Vila Mariana - São Paulo, SP, Brazil - CEP 04012-180

E-mail: r_staico@hotmail.com

Received on: 2/1/2013 • Accepted on: 3/8/2013 
$\mathbf{R}$ adiofrequency ablation has been used in the percutaneous treatment of cardiac arrhythmias for several decades. Recent studies have shown the benefits of percutaneous renal sympathetic denervation as an alternative adjunct strategy for blood pressure control in hypertensive patients resistant to drug treatment.

The formation of lesions by radiofrequency (RF) depends on several factors; the most important are the appropriate electrode-tissue contact, the power used, the application duration, and the type of catheter used. In clinical situations such as ventricular tachycardia, it is essential that the lesion is deep enough to penetrate the myocardial tissue. However, the excessive temperature at the catheter tip can result in thrombus formation, which in turn limits the release of energy and reduces lesion amplitude. Based on these facts, efforts have been made to optimise energy delivery to the tissue without any substantial increase of temperature at the catheter tip. Currently, catheters with continuous irrigation systems are often employed in the treatment of cardiac arrhythmias in order to increase the depth of RF penetration into the tissue. Considering the location of the renal nerves in the vessel adventitia, sometimes located more than 4 $\mathrm{mm}$ from the intima, it is postulated that irrigated catheters could offer advantages in the setting of renal sympathetic denervation. This study aimed to evaluate the performance of irrigated-tip catheters compared to conventional solid-tip catheters in an in vitro experiment.

\section{METHODS}

\section{Study setting}

An acrylic chamber specifically designed to mimic blood flow conditions was used in the study, into which $7 \mathrm{~L}$ of Ringer's lactate solution were inserted, constantly circulating through a pump to simulate the renal blood flow and heated at $37^{\circ} \mathrm{C}$. Six porcine renal arteries were used, each of which was sectioned in its longitudinal axis and attached to the chamber, and then submitted to radiofrequency application.

\section{Procedure}

Three radiofrequency applications were performed in each artery, at different points, with a minimum distance of $10 \mathrm{~mm}$ between them, using different catheters, power settings, and durations of application, resulting in a total of 18 lesions. In each application, the tip of the catheter was placed obliquely to the luminal surface of the artery under constant contact pressure. Three types of catheters were used: $4 \mathrm{~mm} / 5 \mathrm{~F}$ solid tip (Marinr ${ }^{\circledast}$, Medtronic -Minneapolis, Minnesota, United States), 4 $\mathrm{mm} / 7 \mathrm{~F}$ solid tip (Marinr ${ }^{\oplus}$, Medtronic), and $4 \mathrm{~mm} / 7 \mathrm{~F}$ open tip irrigated (Sprinklrø, Medtronic) (Figure 1).

Saline solution $(0.9 \% \mathrm{NaCl})$ at a flow rate of $17 \mathrm{~mL} / \mathrm{h}$ at room temperature was used in the irrigation system of the irrigated-tip catheter. Two powers were applied (8 W and $15 \mathrm{~W}$ ) for 30 seconds, 60 seconds, and 120 seconds.

\section{Microscopic analysis}

Each of the 18 points of RF application was sectioned into fragments of approximately $1 \mathrm{~cm}^{2}$, using a sharp razor to avoid tissue damage; they were then chemically fixed in a formaldehyde 10\% solution in individual and numbered vials, with a solution volume of no less than 40 times the volume of each fragment. Thereafter, each fragment was dehydrated in absolute ethanol, cleared in xylene, and embedded in paraffin blocks. They were then sliced into serial $4 \mathrm{~mm}$ sections using a semiautomatic microtome. Thus, 18 slides for microscopic analysis were made with several serial sections of each tissue and were stained with hematoxylin-eosin. An additional slide with a fragment of porcine renal artery not submitted to RF application was prepared and analysed as control. In cases of doubt regarding the presence of nerve/blood vessels, an immune histochemistry was performed using the S-100 marker protein to precisely identify the location and distribution of nerve fibres. The analysis by optical microscopy was performed in blinded fashion at an independent laboratory, by an experienced professional from the Department of Pathology of Universidade Federal de São Paulo (São Paulo, SP, Brazil).

\section{RESULTS}

In total, 19 slides were analysed, of which 18 had lesions caused by RF application and one served as a control (Figure 2). The RF application with 5F/8W catheter for 30 seconds or 60 seconds resulted in neural damage; however, the presence of multiple nerve fibres, although small, was also observed (Figure 3). When

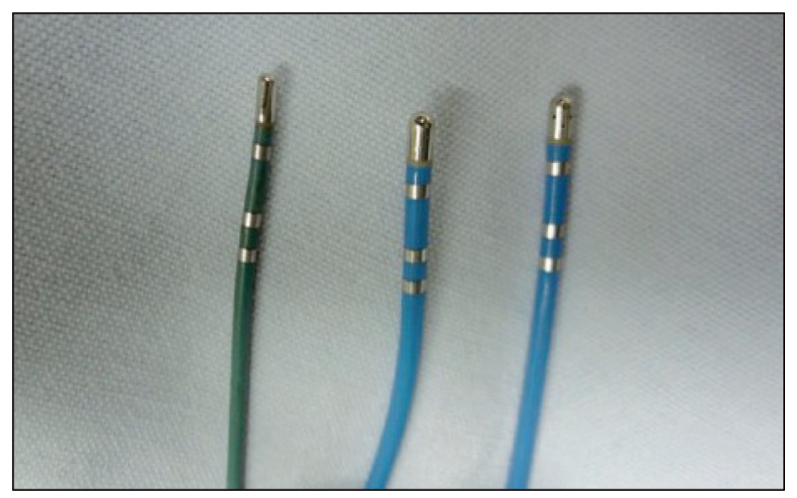

Figure 1 - The three types of catheters used, from left to right: 4 $\mathrm{mm} / 5 \mathrm{~F}$ solid tip (Marinr ${ }^{\oplus}$ ); $4 \mathrm{~mm} / 7 \mathrm{~F}$ solid tip (Marinr ${ }^{\circledR}$ ); and $4 \mathrm{~mm} / 7 \mathrm{~F}$ open tip irrigated (Sprinklr $\left.{ }^{(}\right)$. 
the duration of RF application was increased to 120 seconds, the nerve fibres became rare (Figure 4). The use of $15 \mathrm{~W}$ power resulted in significant nerve reduction, regardless of the catheter used or the duration of RF application. Major structural changes were observed with the $7 \mathrm{~F}$ solid tip catheter and with the irrigated tip catheter, even with lower power and shorter duration of RF application (8 W/30 seconds). Furthermore, RF application using the irrigated-tip catheter at $8 \mathrm{~W}$ for 60 seconds resulted in more extensive and deeper lesions, characterised by complete nerve destruction (Figure 5). Predominant effect on the adventitia of the vessels was observed in all cases; however, the middle

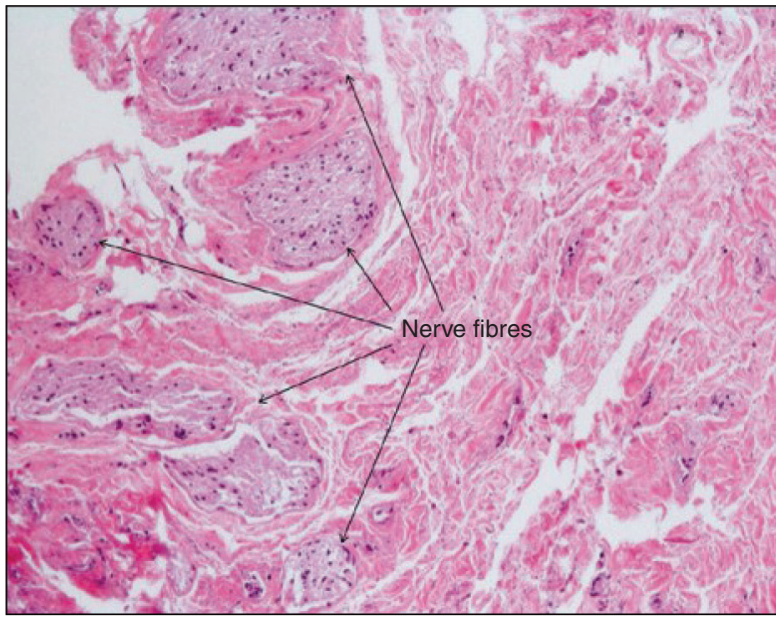

Figure 2 - Microscopic aspect of the control sample showing the presence of large nerve fibres. (200× magnification, hematoxylineosin staining).

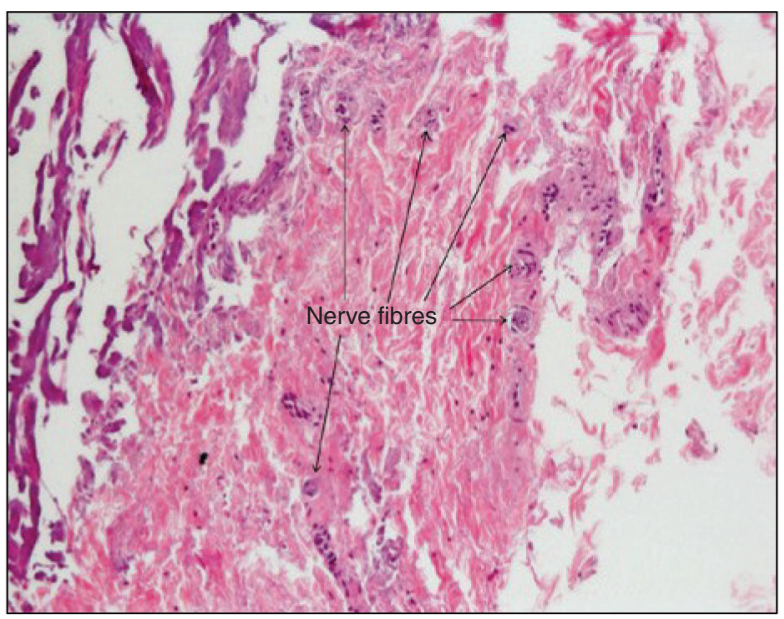

Figure 3 - Microscopic aspect after RF application with 5F solid tip catheter, at $8 \mathrm{~W}$ for 60 seconds, showing neural lesion with multiple and small nerves. (200× magnification, hematoxylineosin staining). layer of the porcine renal arteries was also affected when applying $15 \mathrm{~W}$ with the irrigated-tip catheter, even for 30 seconds (Figure 6). Figure 7 shows a slide prepared by the immune histochemistry technique with S-100 protein, which shows the presence of small and rare nerve fibres. Table 1 presents the data for each RF application and their respective lesions.

\section{DISCUSSION}

Catheter-based renal sympathetic denervation has emerged as an adjunct alternative strategy for blood pressure control in patients with drug-resistant

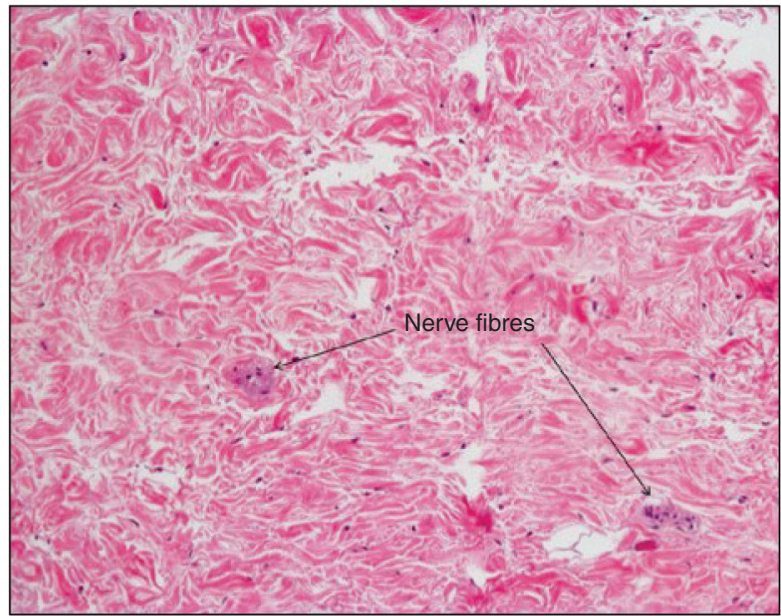

Figure 4 - Microscopic aspect after RF application with 5F solid-tip catheter at $8 \mathrm{~W}$ for 120 seconds, showing neural lesion with rare and small nerves. (200x magnification, hematoxylin-eosin staining).

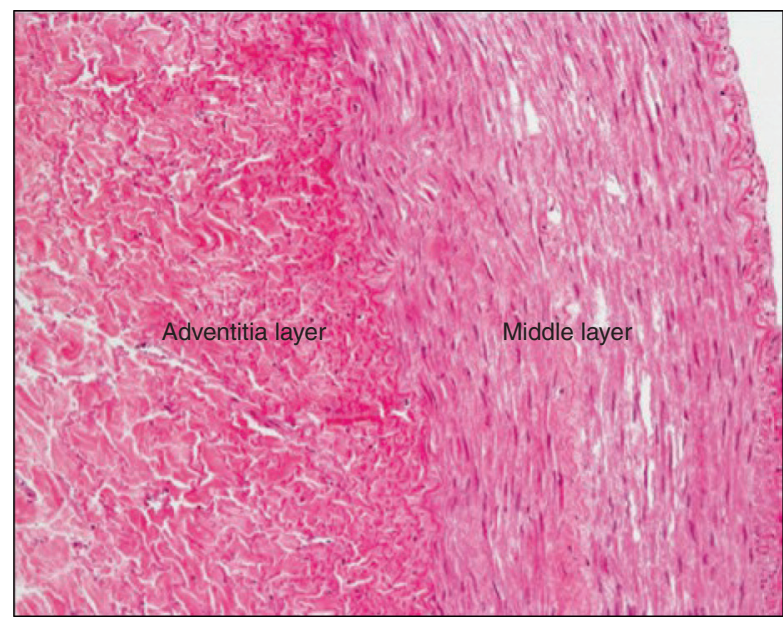

Figure 5 - Microscopic aspect after RF application with irrigated-tip catheter at $8 \mathrm{~W}$ for 60 seconds, showing complete destruction of renal nerves and preserved middle layer. (200× magnification, hematoxylin-eosin staining). 


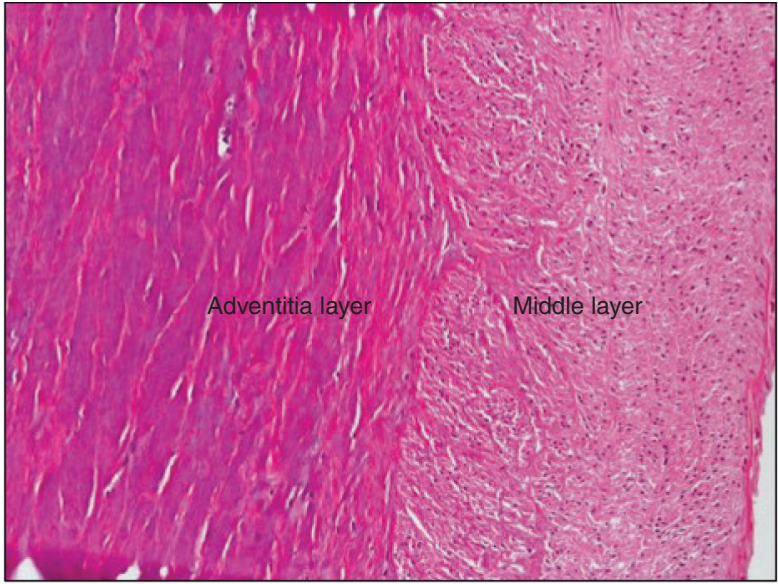

Figure 6 - Microscopic aspect after RF application with irrigated-tip catheter at $15 \mathrm{~W}$ for 30 seconds showing complete destruction of renal nerves and affected middle layer. (200× magnification, hematoxylin-eosin staining).

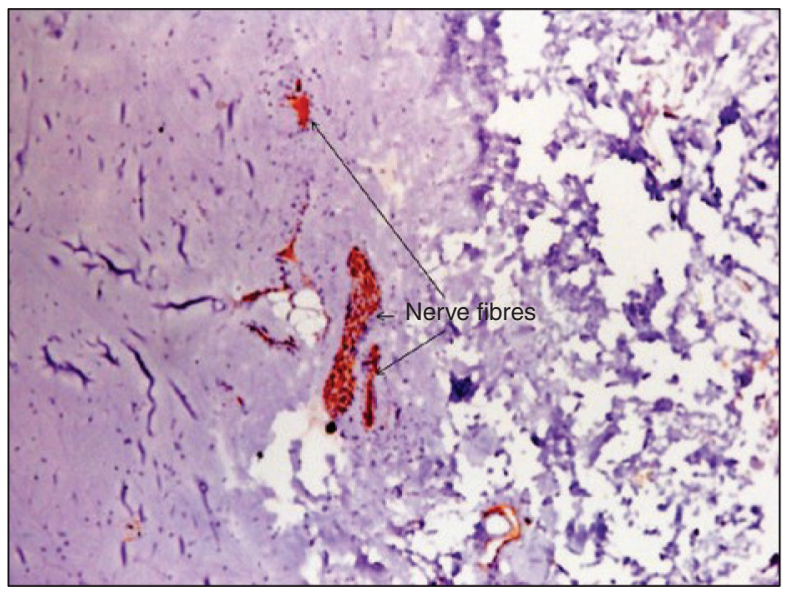

Figure 7 - Microscopic aspect after immune histochemical technique with S-100 protein showing the presence of small and scarce nerve fibres.

hypertension. ${ }^{1,2}$ The most relevant research on this topic to date is the Simplicity HTN-2 Trial. $^{3}$ In this multicentre, randomised study, 106 patients with resistant hypertension were randomised to renal sympathetic denervation by catheter ablation, adjunct to medical therapy or to optimal pharmacological treatment. The authors demonstrated a decrease in blood pressure of $32 / 12 \mathrm{mmHg}$ after six months in the intervention group (standard deviation of 23/11, baseline blood pressure of $178 / 96 \mathrm{mmHg} ; \mathrm{P}<0.0001)$ compared to the control group (change of $1 / 0 \mathrm{mmHg}$ [SD 10/21], basal blood pressure of $178 / 97 \mathrm{mmHg} ; \mathrm{P}=0.77$ for systolic and $\mathrm{P}=0.83$ for diastolic pressure). There were no major complications related to the described procedure. Despite the promising results, the dedicated system for renal ablation used in the Simplicity HTN-2 Trial is not yet available for clinical use in Brazil. Therefore, ablation catheters routinely used in electrophysiology, not primarily designed for renal ablation, have been employed in a non-standardised manner for renal sympathetic denervation in Brazil.

The findings of this in vitro study demonstrate that the irrigated-tip catheter results in deeper lesions when compared to solid-tip catheters in the setting of renal denervation. When using a $4 \mathrm{~mm} / 5 \mathrm{~F}$ catheter with solid tip and power of $8 \mathrm{~W}$ (similar catheter and same power used in the Simplicity HTN-2 Trial), more significant renal neural lesions were observed when the duration of application was extended to 120 seconds (duration of application also used in Simplicity HTN-2 Trial).

The $7 \mathrm{~F}$ solid-tip catheter caused significant neural lesions, regardless of the power used (8 W or $15 \mathrm{~W}$ ) or the duration of RF application (30 seconds, 60 seconds, or 120 seconds). Moreover, the $7 F$ irrigated-tip catheter used for at least 60 seconds of RF application caused complete nerve destruction, and also affected the middle layer when $15 \mathrm{~W}$ of power was applied. These observations reflect the rationale that $5 \mathrm{~F}$ solidtip catheters cause neural injury, but RF applications with 7F catheters, mainly those with open irrigated tips, result in deeper and more intense lesions. Based on these findings, the authors believe that, in cases in which electrophysiology catheters are used as tools for renal sympathetic denervation, the differences between them should be respected, and a standardised RF should be used for each type of catheter, aiming to deliver adequate energy to the tissue regarding efficacy and safety of the procedure. Too little power may be insufficient for the appropriate ablation of the nerves, whereas too much power can cause acute side effects and/or medium - to long-term side effects, such as stenos is or renal artery aneurysm.

The benefits of using the irrigated catheter were demonstrated in the study by Ahmed et al., ${ }^{4}$ in which ten patients with resistant hypertension underwent renal artery ablation. The authors demonstrated a significant reduction in blood pressure at the six-month follow-up $(21 \mathrm{mmHg}$ and $11 \mathrm{mmHg}$ in systolic and diastolic pressure, respectively), with a reduction of at least $10 \mathrm{mmHg}$ in systolic blood pressure (ranging from $10 \mathrm{mmHg}$ to $40 \mathrm{mmHg}$ ) in all cases. There were no reports of steno sis or aneurysm formation in the follow-up kidney angiography at six months. Significant reduction in the levels of metanephrine (-12 [SD $=4] ; P=0.003)$, nor metanephrine $(-18[S D=4]$; $\mathrm{P}=0.0008)$, and aldosterone $(-60[S D=33] ; P=0.02)$ were described at three months of follow-up, with no significant change in plasma renin activity $(-0.2 \mathrm{mg} / \mathrm{L} /$ hod; $\mathrm{P}=0.4)$ and serum creatinine $(-1 \mathrm{mmoL} / \mathrm{L}$; $P=0.4)$. The authors concluded that renal sympathetic denervation can be effectively and safely performed using an irrigated catheter for radiofrequency ablation. 
Table 1

In vitro radiofrequency application in porcine renal arteries using different catheters, powers, durations, and resulting lesions

\begin{tabular}{|c|c|c|c|c|}
\hline Application & Catheter & $\begin{array}{l}\text { Power } \\
\text { (W) }\end{array}$ & $\begin{array}{l}\text { Duration } \\
\text { (seconds) }\end{array}$ & $\begin{array}{l}\text { Findings } \\
\text { (nerves) }\end{array}$ \\
\hline 1 & $4 \mathrm{~mm} / 5 \mathrm{~F}$ & 8 & 30 & Multiple and small \\
\hline 2 & $4 \mathrm{~mm} / 5 \mathrm{~F}$ & 8 & 60 & Multiple and small \\
\hline 3 & $4 \mathrm{~mm} / 5 \mathrm{~F}$ & 8 & 120 & Rare and small \\
\hline 4 & $4 \mathrm{~mm} / 5 \mathrm{~F}$ & 15 & 30 & Rare and small \\
\hline 5 & $4 \mathrm{~mm} / 5 \mathrm{~F}$ & 15 & 60 & Rare and small \\
\hline 6 & $4 \mathrm{~mm} / 5 \mathrm{~F}$ & 15 & 120 & Rare and small \\
\hline 7 & $4 \mathrm{~mm} / 7 \mathrm{~F}$ & 8 & 30 & Rare and small \\
\hline 8 & $4 \mathrm{~mm} / 7 \mathrm{~F}$ & 8 & 60 & Rare and small \\
\hline 9 & $4 \mathrm{~mm} / 7 \mathrm{~F}$ & 8 & 120 & Rare and small \\
\hline 10 & $4 \mathrm{~mm} / 7 \mathrm{~F}$ & 15 & 30 & Rare and small \\
\hline 11 & $4 \mathrm{~mm} / 7 \mathrm{~F}$ & 15 & 60 & Rare and small \\
\hline 12 & $4 \mathrm{~mm} / 7 \mathrm{~F}$ & 15 & 120 & Rare and small \\
\hline 13 & 4 mm/7F irrigated & 8 & 30 & Rare and small \\
\hline 14 & 4 mm/7F irrigated & 8 & 60 & Complete destruction \\
\hline 15 & 4 mm/7F irrigated & 8 & 120 & Complete destruction \\
\hline 16 & 4 mm/7F irrigated & 15 & 30 & $\begin{array}{l}\text { Complete destruction/Lesion } \\
\text { in the middle layer }\end{array}$ \\
\hline 17 & $4 \mathrm{~mm} / 7 \mathrm{~F}$ irrigated & 15 & 60 & $\begin{array}{l}\text { Complete destruction/Lesion } \\
\text { in the middle layer }\end{array}$ \\
\hline 18 & $4 \mathrm{~mm} / 7 \mathrm{~F}$ irrigated & 15 & 120 & $\begin{array}{c}\text { Complete destruction/Lesion } \\
\text { in the middle layer }\end{array}$ \\
\hline
\end{tabular}

\section{Study limitations}

Experimental data provide the basis for the characterisation of the effects of different ablation catheters. However, the results obtained may differ in humans. The electrode-tissue contact pressure, the catheter tip orientation, and the cooling of the porcine renal artery by conversion in an in vitro context may differ from the clinical scenario in humans. In order to simulate renal flow, and since it was more practical, warm Ringer's lactate solution was used rather than heparinised blood, which may result in different degrees of cooling by conversion due to the different heat conduction properties of these two liquid media. Despite these particularities of an in vitro study, the same model was used in all applications, making it possible to compare the different types of catheters and the observed results. The same applies to the pressure exerted on the tissue, which can differ from that exerted by the catheter tip on the renal artery in humans; however, the pressure was constant and uniform during all applications, allowing for the comparison of the effects of different powers and ablation durations with different catheters in this experiment.

\section{CONCLUSION}

Catheters with solid and open irrigated tips produce renal nerve lesions, depending on the power and duration of radiofrequency use. The irrigated-tip catheter results in deeper lesions and may be more beneficial in the adjunct treatment of resistant hypertension, considering the location of the sympathetic nerves in the adventitia layer of the renal artery. Proper choice of the power and duration of application is critical in order to prevent excessive lesion and consequent vascular damage. The clinical applicability of these results should be confirmed. 


\section{CONFLICT OF INTERESTS}

The authors declare to have no conflicts of interests.

\section{ACKNOWLEDGEMENT}

The authors would like to thank the engineer Osvaldo Chumar for his support, dedication, and collaboration during the performance of this study.

\section{REFERENCES}

1. Krum H, Schlaich M, Whitbourn R, Sobotka PA, Sadowski J, Bartus K, et al. Catheter-based renal sympathetic denervation for resistant hypertension: a multicentre safety and proofof-principle cohort study. Lancet. 2009;373(9671):1275-81.

2. Schlaich MP, Sobotka PA, Krum H, Lambert E, Esler MD. Renal sympathetic-nerve ablation for uncontrolled hypertension. $N$ Engl J Med. 2009;361(9):932-4.

3. Esler MD, Krum H, Sobotka PA, Schlaich MP, Schmieder RE, Bohm M. Renal sympathetic denervation in patients with treatment-resistant hypertension (The Symplicity HTN-2 Trial): a randomised controlled trial. Lancet. 2010;376(9756): 1903-9.

4. Ahmed H, Neuzil P, Skoda J, Petru J, Sediva L, Schejbalova M, et al. Renal sympathetic denervation using an irrigated radiofrequency ablation catheter for the management of drug-resistan hypertension. JACC Cardiovasc Interv. 2012;5(7):758-65. 